Industry gets a bargain

\section{London}

BRITISH universities, trying to survive by taking on an increasing number of industrial research contracts, may be undermining themselves instead by failing to charge for overhead costs in full, according to the author of a new report* on British research spending.

Peter Collins and colleagues from the Science and Engineering Policy Studies Unit (SEPSU), run by the Royal Society and the Fellowship of Engineering, have completed the first survey to identify the detailed structure of research spending in a sample of British universities, and government and industrial laboratories. Collins' stark warning on university research contract pricing policy follows a Science and Engineering Research Council (SERC) survey showing that British spending per researcher in higher education institutes lags behind that in preunification West Germany by 40 per cent.

The SEPSU study looked at research spending in 30 laboratories and university departments in 1986-87, separating salaries from all other costs (including equipment, travel, administration and laboratory maintenance). In the universities, these costs varied between 80 and 140 per cent of the salary bill. In industry, this figure rose to between 165 and 240 per cent.

According to Collins, these data show that researchers in industry are, "project for project, better equipped" than their academic counterparts. But he adds that ASTRONOMY

\section{Mt Graham sites cleared \\ Washington}

Although its legal battles are far from over, the University of Arizona has put behind it one of the chief barriers to the construction of the controversial Mount Graham telescopes. After a three-judge panel gave the go-ahead last week, the university quickly felled trees to clear space for the first two telescopes on the sites. Over the protests of environmentalists, 24 of whom were arrested, workers began digging trenches on the sites. With just weeks left to go before the approach of winter stops further work, the construction is largely a symbolic gesture to defuse further lawsuits and to reassure the telescope's German and Vatican partners that progress is being made.

Activists plan to continue the legal battle which has already been running for three years and involved innumerable court hearings (see Nature 344, 479; 1990).

Christopher Anderson the problem of maintaining a 'well found' university laboratory is compounded by the consistent failure of universities to recoup the the full indirect costs of research contracted out from industry.

The old University Grants Committee (now replaced by the Universities Funding Council, UFC) assumed that research project overhead costs are about 40 per cent of the direct costs supplied through a research council grant or industrial contract. Collins says this figure is far too low. Even so, universities on average recovered only 14 per cent of the value of external research contracts to cover overheads in 1988-89, giving the lie to recent accusations from industry that universities are overcharging (see Nature, 347, 216; 20 September 1990). With these external contracts increasing by nearly 14 per cent per year throughout the 1980 s, Collins says universities will be "in trouble", if they do not soon start charging a proper price for their services.

Miles Hedges, the UFC's financial adviser, says the UFC is encouraging vicechancellors to increase their research contract prices. He senses some improvement, but adds "there's an awfully long way to go". Sue Jacobs, from the industrial liasion group at Imperial College London, which has been more successful than most at recovering its overheads, says that (with a few exceptions) industrial companies can be persuaded to pay a fair price for university research. But she finds getting a fair deal from government departments more difficult. The problem, she says, is finding the right government official to negotiate with.

The new SERC survey is the first to calculate research spending per full-time researcher in British universities. It shows that West. Germany spent $£ 80,000$ per academic researcher in 1987 , compared with $£ 48,000$ in the United Kingdom. German academics are better equipped, have more support staff and are better paid than their British counterparts, the report concludes.

British spending seems to compare favourably with that in France $(£ 36,000$ per full-time university researcher). But Harry Atkinson, one of the report's authors, says that this is misleading: French research spending is biased heavily towards the laboratories of the Centre National de la Recherche Scientifique (CNRS), many of which are associated with universities.

If links between universities and CNRS laboratories are taken into account, Atkinson says, French university spending is probably similar to that in the United Kingdom.

Peter Aldhous

* The structure of research expenditure, SEPSU Policy Study 4, obtainable from SEPSU, Royal Society, 6 Carlton House Terrace, London SW1Y 5AG.

\title{
Directors agree on research
}

\section{London}

No research, then no museum. That was the theme of an international conference on the future of scholarship in museums held last week ( 2 October) by the Royal Society of Arts. The message was notably spelled out by Professor Wolf-Dieter Dube, director of the State Museums of the Prussian Cultural Heritage in Berlin.

Continuing controversy over research posts at the Natural History Museum (NHM) in London spilled over into the meeting, which had been arranged long before the NHM crisis had erupted. The museum's director, Dr Neil Chalmers, contributed to a round-table discussion at the end of the meeting.

Also running through the discussion was the general feeling that museums everywhere are common property, and that their managers should maintain the expertise necessary to interpret collections. And museums must convey the essentials of new research to the public without patronizing people.

The Science Museum in London claims to follow the second precept. Popularization, said director Dr Neil Cossons, needs the support of "high-grade scholarship" to make it worthwhile. But he also noted that museums have outgrown the ability of oldfashioned academic museum managers to cope either with themselves or public demand. Victims of their own success, "museums in the past quarter-century have moved from the twilight to the spotlight". Scholars, urged Cossons, must take part in management, and not regard it as "a pollution of the purity of scholarship".

The sheer pace of change has led to confusion. Dr Klaus Sattler, a German researcher currently working at the NHM, commented that compared with the management at the NHM and its neighbour, the Victoria and Albert Museum, "the total collapse of my country in 1945 looks positively well-organized".

Responding to questions about the London NHM's corporate plan, $\mathrm{Dr}$ Michael Novacek, dean of science at the American Museum of Natural History, said he was disturbed at the way in which decisions on priorities had been made and that NHM staff were apparently not consulted about future research directions or warned of the dangers of "jumping on biodiversity bandwagons".

Henry Gee 